\title{
Cytoplasmic Protein NCK2
}

National Cancer Institute

\section{Source}

National Cancer Institute. Cytoplasmic Protein NCK2. NCI Thesaurus. Code C33963.

Cytoplasmic protein NCK2 (380 aa, $\sim 43 \mathrm{kDa}$ ) is encoded by the human NCK2 gene. This protein is involved in the regulation of growth factor receptor signal transduction. 